\title{
Stakeholder Wealth Maximization and the Goal of Financial Management in China
}

\author{
Jinyu TIAN and Ziyuan ZHANG \\ North China Electric Power University, Department of Economics and Management, NCEPU, Baoding, Hebei, China, 071003 \\ 769774965@qq.com, huadianzhangzy@163.com
}

\begin{abstract}
The goal of financial management is one of the basic theoretical issues of financial management. It is also an issue of great concern among finance circles home and abroad. The purpose of this paper is to study stakeholder wealth maximization and the choice of financial management target in China. This paper firstly discusses about the main ideas of the financial management goals, and evaluates the advantages and disadvantages of various viewpoints; then introduces the stakeholder theory. Finally, according to our country national conditions, the paper holds that stakeholder wealth maximization is the rational choice for the goal of financial management. In addition, stakeholder wealth maximization is the goal that suits China.

Index Terms - Stakeholder; Stakeholder wealth maximization; The goal of financial management
\end{abstract}

\section{Introduction}

As a basic theoretic issue of financial management, the goal of financial management has been widely studied and discussed by domestic and foreign academia. In the enterprise, due to the special status of the shareholders, as owners, their interests have attracted much attention. But with the development of the knowledge economy, status of the other stakeholders has been improved. Just focusing on the interests of shareholders unilaterally has been unable to meet the needs of economic and social development. From the view of sustainable development of enterprises, the enterprises should focus on other stakeholders and consider their interests objectives. Making stakeholder wealth maximization as the goal of financial management can make up deficiencies that maximization of shareholders only focus on the interests of shareholders while ignoring other stakeholder, which meets the enterprises' requirements of long-term sustainable development. Therefore, study of stakeholder wealth maximization has its practical meaning ${ }^{[1]}$.

\section{The Main Views on Goal of Financial Management}

\section{A. Profit Maximization}

The goal of profit maximization develops the behavior of the financial management of enterprises towards the direction of maximizing corporate profits, which is under the assumption that investment income has determined. Pursue profit maximization as the goal of financial management, and its advantages are: (1) the purpose of humanity engaged in production activities is to create more surplus products, we can use profit metrics to measure number of surplus products. (2) Profit is the differences between total income and total expenses in a certain period, and is to be calculated in accordance with the principle of matching revenues and costs, which can reflect the level of economic efficiency of enterprises to a certain extent. (3) Profit is the source of increasing investor returns and remuneration of employees, but also the source of accumulating business capital and expanding business scale.

But in practice problems difficult to solve still exists: (1) It does not reflect the relationship between profits and investment capital, is not conducive to compare different capital sizes or different periods of the same enterprise, would mislead corporate taking projects with the higher capital and the lower efficiency for the pursuit of profit maximization, and is not conducive to use funds effectively. (2) Profit index is the total amount of profit for a certain period, without considering the time value of money. (3) Profit maximization does not consider the risk factors, because high profits often accompany by high risk. (4) Pursuing profit maximization one-sided will make financial decisions of enterprises behave a short-term tendency, ignore the product development, human resources development, production safety, welfare facilities, fulfilling social responsibility and other aspects, which is not conducive to long-term healthy development ${ }^{[2]}$.

\section{B. Shareholder Wealth Maximization}

Shareholder wealth maximization is to get the most wealth for shareholders through reasonable financial management. In this view, business owners, the shareholders and managers, is an agency relationship, the manager should seek to maximize the interests of shareholders, and shareholders' goal is to pursue maximizing their wealth. Compared with profit maximization, shareholder wealth maximization has following advantages: (1) The goal of shareholder wealth maximization has considered time and risk factors, because the stock price reflects the current and future corporate value. (2) Shareholder wealth maximization in a way can overcome a short-term tendency behavior of enterprises, because the level of stock prices is not only affected by current profit, but more important is the potential for future development of enterprises. (3) The goal of shareholder wealth maximization is easy to quantify, because the stock price is easily accessible from the stock market, which facilitates assessment and evaluation.

However, there are some drawbacks for shareholder wealth maximization: (1) It only applies to listed companies, most unlisted companies are difficult to use, which limits the use scope. (2) It only emphasizes the interests of shareholders, and ignores the interests of other concerned parties (such as creditors, managers, staff, etc.), which affects the enterprise's production and business activities and is not conducive to 
long-term development. (3) There are some authorities uncontrollable factors in stock prices, such as the external environment limitations, the general level of economic activities and stock market conditions and so on. Importing these factors to financial management goal is unreasonable. (4) In terms of corporate shareholders, aim of its shareholding is not necessarily to pursue the highest price, such as to control the investee company's production activities, thus its sensitivity of stock price is less than individual shareholders, so as its interest to the highest stock price.

\section{Enterprise Value Maximization}

Enterprise value maximization means by reasonable management on corporate finance, to take the best financial policies and take full account of the relationship between monetary value and remuneration. On the basis of ensuring long-term stable development of the enterprise so that the total value of the firm is maximized. This financial goal is to pursue common value maximization for a variety of business stakeholders, rather than only consider shareholder side.

But the goal of enterprise value maximization is also not perfect: (1) Enterprise value maximization does not highlight who owns the business interests. (2) Enterprise value maximization does not correctly handle the relationship between long-term accumulation and allocation of reality. (3) In terms of current less mature capital markets, "enterprise value" in the enterprise value maximization is difficult to accurately measure, the company's stock is difficult to reflect the value of the enterprise. (4) Shareholders who determine the value of the enterprise value maximization goal is inappropriate. (5) Making enterprise value maximization as a financial target is easy to make corporate finance emphasis on long-term planning and ignore short-term benefits and financial management of daily operations. When conflict occurs between short-term decisions and long-term decisions, long-term decisions tend to be chose with orientation of the enterprise value maximization concept. There are big predicted risks with long-term decisions, which may result in decision mistakes.

Through the above analysis we can see, the choice of financial management objectives mainly depends on the choice of business goals. Above views reflect different aspects of the business goals, and has a certain rationality. But they believe that business is only investors' business, which adapts with industrial economy era in the past. They emphasize capital wage labor, capital's owner (investor) hold control of the business and residual claims. Thus target of business services is to ensure the interests of the investors, target of business finance is to maximize the interests of investors correspondingly. However, with the coming of the knowledge economy, continuously improvement in the position of the enterprise of human resources and more scattered shares of the company, the enterprise is no longer merely investors' enterprise. Modern business view tells us: business is a collection of stakeholders, it operates for interests of all parties, the parties in this assembly are considered as contributors and sharers of business interests. Residual claims and control rights are no longer exclusively belong to the investors.
Companies must consider the impact of business activities on the various relevant groups and the whole society, and therefore the target of company financial activities should serve these stakeholders.

\section{Stakeholder Theory}

In 1963, the Stanford Research Institute first proposed the concept of stakeholders. In 1965 American scholar Ansoff first introduced the term to management academia and economy academia, thought that "To specify a desired business goals, we must comprehensively and balanced consider the conflicting claims between many business stakeholders, they may include managers, shareholders, workers, suppliers and distributors." ${ }^{[3]}$ Since 1980, the impact of stakeholder theory began to expand, and promote to change the business management idea and mode. Any business has many stakeholders, as a multi-stakeholder organic combination, its financial management objectives are bound to be affected by various stakeholders' will. Business stakeholders generally include:

(1)Business owners. Business owners provide seed capital to enterprise, its impact on corporate finances primarily achieve by voting rights of the shareholders' meeting and board of directors. Corporate major financial decisions must go through the vote of the shareholders' meeting or the board of directors. Business managers and financial managers' appointment and removal is also determined by the board of directors, so business owners have a significant impact on corporate financial management.

(2)Business creditors. Business creditors are main providers of long and short term funds of enterprises. They lend money to companies, then charge loans and interest when expiring, undertaking certain risks. When creditors provide great amount of loan, they will generally limit behavior of enterprises by terms of the contract, or more directly send supervisory personnel to be involved in business decisionmaking to affect the business operation and financial goals.

(3)Enterprise employees. Enterprise employees include general staff and business managers. They provide enterprises with intellectual and physical labor, and gain reasonable returns. Enterprise employees are corporate wealth creators, they and business interests are closely linked, they have rights to share corporate earnings; When companies fail, they have to bear significant risk, sometimes even more than the shareholders bear. Therefore, when establishing the financial management objectives, we must consider the interests of enterprise employees, particularly under socialism, the interests of them should take full account.

(4)The government. The government provides businesses with a variety of public services, but the government also has its own goals, such as to stabilize the economy, reduce unemployment, protect the environment and so on. The Government will changes corporate earnings function through taxation, administrative enforcement and other means, in order to achieve their goals. Thus the decision of enterprise financial management's objectives should also take the government factors into account. 
(5)Customers, suppliers and the public. Large customers and suppliers who have specific contractual relationships with corporate, both provide enterprises with a more stable "market capitalization", so companies cannot ignore their interests. In addition, companies should consider the public's demand that companies should fulfill social responsibility, such as to safeguard the public interest, to protect ecological balance, to prevent pollution hazards, to support to develop community public welfare undertakings and so on.

Thus, when determining the financial management's objectives, companies must reasonably take the interests of all parties into account, which includes the owner, never favoritism or loss. The relationship between the various stakeholders is "cooperative partnership", which stresses the "multi-win". Only this way can we correctly handle the relationship between the economic interests of all parties, make the financial distribution policy maintain homeostasis and get trust and support of all stakeholders, so as to ensure normal production and operation of enterprises, and to achieve sustained and stable development.

\section{Choice of Enterprise Financial Management's Goals in China}

Maximization of stakeholders means by reasonable management on corporate finance, use optimal financial policy, take full account of the relationship between the time value of funds and risk and reward and make stakeholders wealth maximized on the basis that to ensure long-term stable development of enterprises. This financial management's goals should be the optimal choice of enterprise in China. Followings are reasons:

(1)Stakeholder wealth maximization reflects the company's sharing ownership. With the refinement of social division of labor, enhancements of specificity of human capital and expanding business risks, risk takers have become from sole shareholder to the shareholders, creditors, managers, employees, etc.. Since various stakeholders have a certain amount of investment to business, they all take some investment risks, and therefore can gain corresponding share of corporate earnings. In this sense, the residual claims should be shared by a number of stakeholders including shareholders. From the perspective of property rights theory, based on the stakeholder theory, the goal of stakeholder wealth maximization is more adaptable with the situation of contemporary business ownership's sharing than shareholder wealth maximization.

(2)Stakeholder wealth maximization follows the "shared governance" logic. In the market economy, enterprises are actually a set of aggregate of multilateral contractual relationships, the stakeholders' equality and independence contained in contract itself requires that main parts' relationships of corporate governance should be equal and independent. Therefore, we must conclude long-term contracts to ensure a predictable interest compensation. This "shared governance" model helps to ensure long-term cooperation of stakeholders, which also makes stakeholder wealth maximization become better choice for enterprise financial management's goals ${ }^{[4]}$.

(3)Stakeholder wealth maximization highlights the importance of human capital. In the knowledge economy, importance of human capital for companies becomes significantly higher than any of the times. Goals of stakeholder wealth maximization not only take account of the traditional rights of the owners of physical capital, but also pay attention to the rights of the owners of human capital. At this level, the goal of stakeholder wealth maximization precedes other financial goals which just consider one kind of stakeholder .

(4)Stakeholder wealth maximization unifies economic and social efficiency. The goal of stakeholder wealth maximization not only take account of economic efficiency of enterprises, but also corporate social efficiency, social progress, economic development, environmental protection and shared interests of other aspects, which should also be taken seriously in enterprises. While the commitment to social responsibility would reduce profits in short term, but a good social environment and ecological environment plays a crucial role for sustainable development of enterprises. Thus, the goal of stakeholder wealth maximization which takes social efficiency into account is a reasonable choice for enterprises.

\section{Conclusion}

In short words, determining the target of company's financial management as stakeholder wealth maximization not only expands the considered scope of financial management activities, but also embodies the essence of the modern enterprise. At the same time, stressing stakeholder wealth maximization is more in line with the requirements of China's socialist market economy. Chinese enterprises should emphasize the interests of workers and the contributions to society. Therefore, as the goal of China financial management, stakeholder wealth maximization is the best choice at present.

\section{References}

[1] Chen Li, "Study of financial targets based on stakeholder theory," Accounting Communication and Financing, July 2008.

[2] Shan Zhanxiang and Cao Jixia, "Realistic choices of financial management's goals in China," Liaoning University, March 2005.

[3] Tian Li, "Discuss of stakeholder value maximization becoming financial goals," Consumption Guide, vol. 16, 2008, pp. 82+84.

[4] Shi Qing, "Objectives of financial management to maximize the interests of stakeholders - the selection of Chinese financial management's objectives," Shanghai International Studies University, 2004. 